\title{
Roles of Dietary Phytoestrogens on the Regulation of Epithelial-Mesenchymal Transition in Diverse Cancer Metastasis
}

\author{
Geum-A. Lee, Kyung-A. Hwang * and Kyung-Chul Choi * \\ Laboratory of Biochemistry and Immunology, College of Veterinary Medicine, Chungbuk National University, \\ Cheongju, Chungbuk 361-763, Korea; mmanuraa@gmail.com \\ * Correspondence: hka9400@naver.com (K.-A.H.); kchoi@cbu.ac.kr (K.-C.C.); \\ Tel.: +82-43-249-1745 (K.-A.H.); +82-43-261-3664 (K.-C.C.); Fax: +82-43-267-3150 (K.-A.H. \& K.-C.C.)
}

Academic Editor: Carmela Fimognari

Received: 6 March 2016; Accepted: 19 May 2016; Published: 24 May 2016

\begin{abstract}
Epithelial-mesenchymal transition (EMT) plays a key role in tumor progression. The cells undergoing EMT upregulate the expression of cell motility-related proteins and show enhanced migration and invasion. The hallmarks of EMT in cancer cells include changed cell morphology and increased metastatic capabilities in cell migration and invasion. Therefore, prevention of EMT is an important tool for the inhibition of tumor metastasis. A novel preventive therapy is needed, such as treatment of natural dietary substances that are nontoxic to normal human cells, but effective in inhibiting cancer cells. Phytoestrogens, such as genistein, resveratrol, kaempferol and 3,3'-diindolylmethane (DIM), can be raised as possible candidates. They are plant-derived dietary estrogens, which are found in tea, vegetables and fruits, and are known to have various biological efficacies, including chemopreventive activity against cancers. Specifically, these phytoestrogens may induce not only anti-proliferation, apoptosis and cell cycle arrest, but also anti-metastasis by inhibiting the EMT process in various cancer cells. There have been several signaling pathways found to be associated with the induction of the EMT process in cancer cells. Phytoestrogens were demonstrated to have chemopreventive effects on cancer metastasis by inhibiting EMT-associated pathways, such as Notch-1 and TGF-beta signaling. As a result, phytoestrogens can inhibit or reverse the EMT process by upregulating the expression of epithelial phenotypes, including E-cadherin, and downregulating the expression of mesenchymal phenotypes, including $N$-cadherin, Snail, Slug, and vimentin. In this review, we focused on the important roles of phytoestrogens in inhibiting EMT in many types of cancer and suggested phytoestrogens as prominent alternative compounds to chemotherapy.
\end{abstract}

Keywords: dietary phytoestrogens; DIM; kaempferol; resveratrol; genistein; epithelial-mesenchymal transition; cancer metastasis

\section{Introduction}

Phytochemicals are chemical compounds that occur naturally in plants, amounting to as many as 4000 different chemicals. Some phytochemicals have the biological significance of inhibiting the invasion of different species of plants by acting as toxic compounds [1,2]. This characteristic of phytochemicals has been utilized in curing diverse human diseases. A vast array of plant-derived natural compounds has been reported to have substantial chemopreventive effects against cancer, in opposition to the health risk of environmental carcinogens [3]. At present, inhibiting human carcinogenesis using plant-derived compounds is considered as a vital and urgent challenge, despite some phytochemicals having been used for targeting many forms of cancer as major sources of highly effective conventional drugs [4-6]. 
Among diverse groups of phytochemicals, phytoestrogens, which are plant-derived xenoestrogens and mostly found in soy, vegetables and fruits, are considered as strong sources of cancer-preventive phytonutrition to inhibit the development and progression of many types of cancer [4,7].

As a kind of xenoestrogen, phytoestrogens specifically have distinctive cancer-preventive effects on estrogen-related cancers. In general, sex hormones, including estrogens, have been known to be closely linked to the pathogenesis of several types of cancer in the reproductive organs [8-10]. Many diseases, like breast, ovarian, endometrial and cervical cancers, have been called estrogen-receptor (ER)-positive cancers, because the actions of estrogen related to cancer biology are mediated via ERs, which comprise $\mathrm{ER} \alpha$ and $\mathrm{ER} \beta$, mostly present in the nucleus [11,12]. Independently of endogenous estrogens, selective estrogen receptor modulators (SERMs), which are a class of drugs that act on ER, act with agonistic or antagonistic actions in several target tissues [13]. Phytoestrogens, which are also a kind of SERM, are known to bind ER with affinities at least 10,000-times lower than that of $17 \beta$-estradiol (E2) and also act as ER agonists or antagonists [14]. The chemopreventive effects of phytoestrogens are associated with their antagonistic effects on ER [15]. In addition to the actions of phytoestrogens via ERs, they could have protective effects on the initiation and progression of estrogen-related cancers by specifically inhibiting the circulating precursors of estrogens [16-20]. In addition, they can inhibit crucial steroidogenic enzyme activity, including the conversion of E2 from circulating hormones, such as androgens and estrogen sulfate [20]. In estrogen biosynthesis and metabolism, phytoestrogens have been shown to inhibit several crucial enzymes in aromatase pathway, such as $17 \beta$ - and $3 \beta$-hydroxysteroid dehydrogenase (HSD), which catalyze the dehydrogenation of 17-hydroxysteroids in steroidogenesis and control the interconversion of androstenedione and testosterone, and E2 and estrone, respectively [21,22].

Phytoestrogens are generally classified into four main classes: isoflavones (genistein, daidzein, kaempferol), lignans (secoisolariciresinol, matairesinol, pinoresinol, lariciresinol), coumestan (coumestrol) and stilbenes (resveratrol) [23,24]. Western populations have been known to intake more foods containing lignans, while Asian populations eat more soy foods containing isoflavones [25]. Lignans are included in diverse groups of non-flavonoid compounds widely distributed in whole grain cereals, beans, berries, nuts and various seeds [26,27]. A wealth of lignans exists as secoisolariciresinol, matairesinol, lariciresinol and pinoresinol, and they are converted into enterolignans by the intestinal microbiota to be absorbed into the human body [27,28]. Tea, fruits, vegetables and grains account for over $85 \%$ of the daily intake of lignans, such as matairesinol and secoisolariciresinol [29]. Isoflavones are naturally-occurring phenolic flavonoid compounds, known to act as phytoestrogens in mammals. Soybeans are the most common source of isoflavones among vegetables; the major isoflavones in soybean are genistein and daidzein, which are well-known phytoestrogens [30]. Coumestans occur mainly in bean sprouts during germination, and the main compound in this subgroup is coumestrol, mostly found in peas and beans [23]. Stilbenoids are hydroxylated derivatives of stilbene and belong to the family of phenylpropanoids [31]. Resveratrol is a typical stilbenoid, which is mainly found in grapes and wines [32].

In the present article, we will review the effect of four kinds of phytoestrogens, genistein, resveratrol, kaempferol and 3,3'-diindolylmethane (DIM), on cancer progression via epithelial-mesenchymal transition (EMT). As shown in Figure 1, genistein, kaempferol and resveratrol are phenolic compounds: genistein and kaempferol are isoflavones, having a common flavone structure; resveratrol is a derivative of diphenylethane; and DIM is an active indole compound originated from indole-3-carbinol (I3C), an inactive form of indole. They are actively-studied phytoestrogens that have great potential to display anti-cancer effects. 
<smiles>O=c1c(-c2ccc(O)cc2)coc2cc(O)cc(O)c12</smiles><smiles>Oc1ccc(C=Cc2cc(O)cc(O)c2)cc1</smiles><smiles>O=c1c(O)c(-c2ccc(O)cc2)oc2cc(O)cc(O)c12</smiles>

Kaempferol<smiles>c1ccc2c(Cc3c[nH]c4ccccc34)c[nH]c2c1</smiles>

Diindolymethane

Figure 1. Chemical structures of phytoestrogens, genistein, resveratrol, kaempferol and 3,3'-diindolylmethane (DIM).

EMT plays a key role in tumor progression. The cancer cells undergoing EMT increase the expression levels of cell motility-related proteins and show enhanced migration and invasion to other sites of the body, resulting in cancer metastasis [33]. It has been found that crucial EMT markers, such as E-cadherin and Snail, are identified to secure positive evidence of EMT, and several signaling pathways are associated with the induction of EMT process in cancer cells, including Not-1 and TGF-beta signalings. In the next section, the importance of EMT in cancer progression, diverse EMT markers and related signaling pathways are briefly introduced to further highlight the impact of these phytoestrogens in chemoprevention against cancer.

\section{Epithelial-Mesenchymal Transition in Cancer Metastasis}

According to the World Cancer Report 2014 of the World Health Organization (WHO), about 14.1 million new cases of cancer occurred globally in 2012, leading to $14.6 \%$ of all human deaths. Approximately $90 \%$ of all cancer-related deaths are reported to be associated with tumor metastasis [34]. The chance of having an invasive cancer in one's lifetime is estimated to be $42 \%$ for men and $38 \%$ for women [35]. The characteristic of cancer malignancy and metastasis is the propagation of primary tumors through migrating to and invading the surrounding tissues [36]. Tumor cells have the potential to invade other tissues and to form metastasis through multiple steps known as malignant progression [37].

The program responsible for profound modification for metastasis that enables detaching from the junctions and dismissing the lateral cell-cell adhesions of cancer cells is EMT [38]. Tumor cells undergoing EMT display unique phenotypes, express higher levels of cell motility proteins and show promoted migration and invasion abilities [39].

EMT is associated with several major characteristics of cellular phenotypes. Through this process, epithelial cells change the morphology from a cobblestone-like monolayer with apical basal polarity to flat and spindle-shaped mesenchymal cells in the absence of polarization to gain the ability to move [40].

To acquire the moving ability, epithelial cells lose their ability to maintain the entire junction complex that connects them to the neighboring ones, of which basolateral surfaces are regularly spaced through membrane-associated specialized junctions [41]. In the process in which epithelial cells are switched to mesenchymal cells, the formation of a space where a barrier and rigidity are maintained is inhibited due to the lack of intercellular junctions [42]. A number of cells undergoing EMT develop interactions with the extracellular environment in localized areas of the carcinoma, where they 
involve the loss of intercellular cohesion, the disruption of extracellular matrix (ECM), modifications of the cytoskeleton, increased motility and invasion into the extracellular space [43]. Particularly, EMT is related to the expression of extracellular matrix proteases, such as matrix metalloproteases (MMPs) and urokinase-type plasminogen activator (uPA), which can degrade the ECM linked to the plasma membrane and localized to invadopodia during metastasis [44-46]. Meanwhile, EMT is a reversible process that can convert to its inverse process, called the mesenchymal-epithelial transition (MET). The cells undergoing MET increase cell-cell adhesion and return to epithelial phenotypes, which also play a role during embryonic development and pathological processes [47,48]. As a result, primary cancer cells lose cell-cell adhesion via EMT by E-cadherin repression, break through the basement membrane and enter the bloodstream through intravasation. Later, the circulating tumor cells exit the bloodstream to migrate to the specific metastatic sites where they undergo MET for clonal outgrowth [49].

A diversity of molecules associated with the process of EMT has been established, and some crucial molecules have been employed as biological markers to determine the process. As a typical molecule in the adherent junctions, E-cadherin, which is a transmembrane glycoprotein of the type I cadherin family and a crucial epithelial marker, has been found to inactivate and repress tumor progression by maintaining intact cell-cell interactions and inhibiting cell mobility, invasion and metastasis in human cancer [50,51]. The loss of E-cadherin expression is allowed for a critical step in the progression of invasive carcinoma by causing the EMT event. The loss of many epithelial markers (including E-cadherin, occludin, claudins and beta-catenin) induces the expression of mesenchymal markers (including $N$-cadherin, Snail, vimentin, R-cadherin and cadherin-11) and acquisition of mesenchymal characteristics, such as cell motility and invasion [52,53]. Additionally, the zinc-finger transcription factors, including Snail, Slug, and ZEB 1 and 2, have been shown to induce the EMT process by directly binding to the E-box of the E-cadherin promoter and suppressing the activity of E-cadherin [54], while Twist, another type of E-cadherin repressor, indirectly downregulates E-cadherin transcription [55].

It has been found that crucial EMT markers are associated with several signaling pathways in the induction of the EMT process in cancer cells. Snail has been found to be a critical factor in TGF- $\beta$ signaling to resist cell death and to inhibit apoptosis [56]. As the most important factor that triggers EMT, TGF- $\beta 1$ mediates the EMT process via numerous intracellular signaling pathways, including the Smad pathway, mitogen-activated protein kinases (MAPK), PI3K/Akt and small GTPases in HL-60 leukemia, Panc-1 human pancreatic and MDA-MB-231 breast cancer cells [57-59]. The overactivation of the TGF- $\beta$ pathway in hepatocellular carcinoma cells confers a mesenchymal-like and an increased migratory capacity to the cells and finally contributes to tumor progression thorough the crosstalk with the chemokine CXCL12 pathway in liver tumor cells [60]. The Wnt signaling pathway activates $\beta$-catenin and several EMT-inducing transcription factors, such as Slug and Twist [34]. This signaling pathway induces cancer cell proliferation, motility and intravasation. Furthermore, in in vivo studies, the Wnt pathway displayed an important role in regulating EMT progression of colorectal cancer [61], and the Wnt- $\beta$-catenin was activated in the mesenchyme of the cardiac cushion during EMT in zebrafish and mouse embryo [62,63]. The cancer development of organs has been regulated by Notch-1 signaling, which directly promotes Snail, Slug and NF-кB in BxPC-3 human pancreatic cancer cell [64]. Notch-1 signaling also induced cell proliferation, survival and EMT by increasing NF- $\mathrm{B}$ transcriptional activity in many human malignancies, including pancreatic and breast cancer cells $[65,66]$. In addition, the Hedgehog $(\mathrm{Hh})$ signaling pathway is currently considered as a therapeutic target for anti-cancer treatment, because this pathway is abnormally activated in various types of cancer and contributes to tumor metastasis by inducing EMT. The misregulation of Hh signaling has been implicated as an important mediator in human pancreatic carcinoma, and specifically the sonic hedgehog pathway promotes metastasis and lymphangiogenesis via activation of Akt, EMT and the MMP-9 pathway in gastric cancers $[67,68]$.

Recently, microRNAs (miRNAs) are being considered as an important regulator of EMT in various cancer cells. They incompletely bind to the $3^{\prime}$ untranslated region ( $\left.3^{\prime} \mathrm{UTR}\right)$ of mRNA to inhibit the 
translations [69]. The incomplete accordance between miRNAs and their targets allows the chances for miRNAs to control multiple genes. Moreover, miRNAs have been shown to play a crucial role during caner development and progression via the modulation of the expression of their target mRNA transcripts [70]. High miR-34a levels stimulate MET by reversing Snail and TCF- $\beta$-induced EMT [71]. As a negative regulator in the EMT process, miR-125a induced MET by the epidermal growth factor receptor (EGFR) signaling pathway [72]. miR-506 suppresses EMT, cell proliferation, migration and invasion by upregulating E-cadherin [73]. miR-138 also has a role in the inhibition of EMT and invasion in SKOV-3 ovarian cancer cells [74]. Another miRNA, miR-30a, was reported to suppress cell motility and EMT via targeting the expression of mesenchymal markers, thereby increasing the epithelial marker in A549 lung and BGC-823 gastric cancer cells $[75,76]$. On the other hand, miR-106a is associated with cell proliferation and tumor differentiation, and miR-7 is linked with metastasis and EMT [77]. In the case of miR-10b, its high expression upregulated the EMT and the expression of EMT-related proteins in metastatic tumors and induced the changed spindle-like morphology, cell migration and overexpression of $N$-cadherin, Snail, Slug and Twist [78,79]. Specifically, the miR-200 family is significant for reducing the ZEB levels, cell migration and TGF- $\beta$-induced EMT [80,81]. Expression of the miR-200 family was increased or decreased in the process of metastasis: miR-200 was downregulated in the EMT process, while it was upregulated during the re-epithelialization of distal metastasis [82].

\section{Phytoestrogens and Their Actions on Cancer Cells Undergoing EMT}

Since the dysregulation of proteins in signaling pathways involved in EMT is associated with cancer progression, they could be potentially targeted as prognostic markers or therapeutic targets of cancer metastasis [83]. Phytoestrogens having a chemopreventive effect on cancer progression seem to inhibit the EMT process through various channels.

\subsection{Genistein}

Genistein (40,5,7-trihydroxyisoflavone), having a heterocyclic diphenolic structure similar to estrogen, is a typical isoflavonoid found in a number of plants, including soybeans, peas, lentils and other beans $[84,85]$. As a phytoestrogen, it has an ability to bind and activate ERs, preferentially ER $\beta$ rather than ER $\alpha[86,87]$. The higher binding affinity for ER $\beta$ of genistein has been associated with its action as an estrogen antagonist and having chemopreventive activity in estrogen-responsive cancers [88].

Anti-proliferative and chemopreventive effects of genistein have been extensively investigated in hormone-related, as well as non-hormone-related cancers in which genistein affects many crucial cellular functions related to carcinogenesis, including cell proliferation, apoptosis, cell cycle progression, migration, metastasis and invasion [89]. Recent studies have elucidated that genistein may have the potential to inhibit cancer metastasis by specifically regulating the EMT process via diverse signaling pathways.

Notch-1 signaling is an important pathway to upregulate the expression of EMT markers, ZEB1 and 2, Slug and vimentin, leading to the EMT, migration and drug resistance of pancreatic cancer cells [90,91]. In AsPC-1 pancreatic cancer cells, Notch-1 overexpression affected the expression of miRNAs: overexpression of Notch-1 led to increased expression of miR-21 and decreased expression of miR-200b. Re-expression of miR-200b led to inhibition of the EMT process by inducing decreased expression of ZEB1 and vimentin and increased expression of $E$-cadherin. Genistein treatment was found to attenuate the acquisition of EMT by AsPC- 1 cells by promoting re-expression of miR-200b, which was repressed by Notch-1 signaling [90].

In a recent study, genistein suppressed the EMT of BG-1 ovarian cancer cells, which was activated by E2 and endocrine-disrupting chemicals, such as bisphenol A (BPA) and nonylphenol (NP), by downregulating the TGF- $\beta$ pathway [92]. As a result, genistein not only suppressed the migration of BG-1 cells, but also diminished the expression of mesenchymal markers (vimentin) and metastasis 
markers (MMP-2 and cathepsin D) [92]. Genistein also effectively inhibited TGF- $\beta$-induced invasion and metastasis in the Panc-1 pancreatic cancer cell line through Smad4-dependent and independent pathways through p38 MAPK [58]. The EMT process was also reversed by genistein in the HepG2 hepatocellular carcinoma cell line by downregulating the nuclear factor of activated $\mathrm{T}$ cells 1 (NFAT1) [93]. NFAT1 was known to function in cell-autonomous actions, like invasion, migration, differentiation and proliferation in tumors [94]. Although the underlying mechanism has not been found yet, genistein suppressed invasive growth of LNCaP prostate cancer cells through the reversal of EMT, even at low concentrations (less than 15 micromoles/L genistein), which did not affect cell proliferation [95].

\subsection{Resveratrol}

Resveratrol (trans-3,4,5-trihydroxystilbene) is one of the stilbene phytoalexins, first found in the roots of the oriental medicinal plant Polygonum cuspidatum (Kojo-kon in Japanese) [96], and also exists in diverse vegetables, including berries, peanuts and red grape [97]. Resveratrol is known to be produced naturally when the plant is injured under attack by pathogens, such as bacteria or fungi [98]. Therefore, the proper infection of Botrytis cinerea (the fungus responsible for grey mold) is needed to obtain maximal concentrations of resveratrol within wine [99]. The characteristic of resveratrol as a phytoestrogen has been verified by its capability to mainly bind to ER and to regulate the transcription of estrogen-responsive target genes [100]. Many studies showed that resveratrol binds to ER $\beta$ with a higher affinity than to ER $\alpha$, though it binds with 7000-fold lower affinity than E2, and that it acts as an agonist or an antagonist in the cells expressing ER [101,102]. Resveratrol can also regulate androgen receptor (AR)-mediated actions as a chemopreventive agent against prostate cancer: it inhibited androgen-stimulated cell growth and gene expression by repressing the expression and function of the AR in LNCaP prostate cancer cells [103].

In addition to its sex hormone-related actions, resveratrol has been found to be very helpful in inhibiting diabetes, heart disease and diverse cancers, because it possesses various bioactive properties, such as anti-oxidation, anti-proliferation, anti-inflammation and induction of apoptosis [104]. Specifically, the anti-oxidative efficacy of resveratrol to prevent the ROS generation and oxidative stress that may drive epithelial cells into an EMT program can be an effective characteristic of resveratrol to prevent the EMT of cancer cells. Actually, modulation of oxidative stress may be an efficient therapeutic tool for the inhibition of cancer progression [105]. Resveratrol inhibited the hypoxia-enhanced proliferation, invasion and EMT process in Saos-2 osteosarcoma cells via downregulation of the HIF-1 $\alpha$ protein [106]. A previous study also revealed that resveratrol effectively suppressed the hypoxia-driven ROS-induced invasive and migratory ability of pancreatic cancer cells by inhibiting the Hh signaling pathway, which is able to regulate the EMT [107].

In addition, a recent finding indicated that resveratrol suppressed invasion and metastasis in gastric cancer by inhibiting the Hh signaling pathway and EMT [108]. In PC-3 and LNCaP prostate cancer cell lines, lipopolysaccharide (LPS) was used to trigger EMT, but resveratrol inhibited LPS-induced morphological changes, cell motility and invasiveness, the expression of EMT markers and inhibited the expression of glioma-associated oncogene homolog 1 (Gli1), suggesting that resveratrol has in part the ability to inhibit the EMT process through the Hh signaling pathway [109].

Similar to genistein, resveratrol abrogates the TGF- $\beta 1$-induced EMT process for cancer progression. In LoVo colorectal cancer cells, resveratrol inhibited the invasive and migratory ability of LoVo cells, increased the expression of $E$-cadherin and repressed the expression of vimentin, via the inhibition of the TGF- $\beta 1 /$ Smads signaling pathway [110]. Other studies also support the role of resveratrol in EMT inhibition. Xu et al. reported that resveratrol reversed EMT by inhibiting AKT signaling in pancreatic cancer [111]. Previously, AKT1 was also shown to promote EMT, as well as to increase metastasis in squamous cancer and sarcoma [112]. On the contrary, AKT1, but not AKT2 and AKT3, inhibited EMT in breast cancer, depressing Twist1 activation [112]. In the MCF-7 breast cancer cell line, resveratrol was found to inhibit EGF-induced EMT via inhibition of the EGF-mediated Erk pathway 
activation [113]. The role of resveratrol in inhibiting EMT induction was demonstrated in A549 lung cancer cells [114].

\subsection{Kaempferol}

Kaempferol (3,5,7-trihydroxy-2-(4-hydroxyphenyl)-4H-1-benzopyran-4-one) is one of the flavonoids found in many edible plants, like tea, broccoli, cabbage, beans and tomato, and its name was derived due to its specific source of the rhizome of Kaempferi galangal L., known as a popular traditional aromatic plant $[115,116]$. As one of the phytoestrogens due to its polyphenolic structure, kaempferol also exerts anti-proliferative and anti-carcinogenic actions though ER, AR, the aryl hydrocarbon receptor (AhR) and the progesterone receptor (PR) signaling pathways in many types of cancer [117-119].

Apoptosis is one of the main pathways for kaempferol to induce the anti-carcinogenic effect. In some cells, kaempferol induced apoptosis by stimulating the enzyme activity of caspases, which are a group of the cysteine proteases that are important initiators or effectors of the apoptosis process [65]. For caspase-3, it activates apoptosis by inducing DNA fragmentation and chromatin condensation in nucleus [120]. Kaempferol decreased the mitochondria potential by the stimulation of caspase-3 activity, resulting in the apoptosis of human lung non-small carcinoma cells [121,122]. In caspase independent pathways, kaempferol also promoted apoptosis by translocating apoptosis-inducing factor (AIF) into nucleus. AIF, which exists mainly in the space between the inner and outer mitochondrial membrane, was translocated into nuclei by kaempferol to induce nuclear condensation and large-scale DNA fragmentation [123,124].

Kaempferol also seems to inhibit cancer invasion and metastasis via the inhibition of EMT. Specifically for lung cancer, kaempferol was well known to suppress cancer migration, invasiveness and metastasis by modulating the expression of EMT proteins. Kaempferol significantly reduced the expression of MMP and mesenchymal markers and repressed metastasis and EMT by the TGF- $\beta$-dependent signaling pathway in non-small cell lung cancer [125]. In A549 lung cancer cells, kaempferol exerted the suppression of TGF- $\beta 1$-induced EMT, migration and metastasis by blocking Smad3 as an important mediator of TGF- $\beta$ signaling. In this study, PI3K/Akt signaling stimulated EMT and cell migration by directly phosphorylating Smas3, but kaempferol repressed EMT and cell migration by inhibiting Akt1-mediated phosphorylation of Smad3 [126]. The effect of kaempferol on EMT in relation to cancer progression has not been fully demonstrated yet, except for lung cancer. Although not in cancer, kaempferol was found to alleviate fibrotic airway remodeling via bronchial EMT by modulating protease-activated receptor-1 (PAR1) activation, which was entailed by TGF- $\beta$, suggesting that it may be a potential therapeutic agent targeting asthmatic airway constriction [127]. Since kaempferol is considered to have obvious anti-EMT efficacies, it will be applicable to other cancers for the prevention of cancer metastasis induced by EMT. According to a recent review on ribosomal S6 kinase (RSK) isoforms, the synthetic version of kaempferol, kaempferol-glycoside, can effectively target the invasion and metastasis of cancer by inhibiting RKS isoforms that promote invasion and tumor metastasis [128].

\subsection{DIM}

Brassica vegetables, such as cabbage, Brussels sprouts and broccoli, are rich in indole-3-carbinol (I3C), which is one of the active phytonutrients and a precursor of many different compounds, especially DIM. I3C undergoes acid-catalyzed dehydration and polymerization to be DIM in an acidic environment [129].

DIM has been shown to abrogate the proliferation of human cancer cells of prostate, breast, colon, ovary and pancreas [130]. Especially, it has the potential role of AhR signaling by acting as one of the selective AhR modulators (SAhRMs) in mammary carcinogenesis prevention [131]. With respect to anti-cancer mechanisms, DIM encourages apoptotic cell death by downregulation of NF- $\mathrm{KB}$, survivin and Bcl-2 as anti-apoptotic factors and upregulation of Bax, a pro-apoptotic 
factor [132,133]. One surprising ability of DIM as a potential anti-cancer compound is its selective induction of apoptosis in cancerous cells, but not in normal cells [134]. Furthermore, DIM activates cell cycle modulators, p21 and p27, leading to G1 cell cycle arrest in breast, ovarian, prostate and colon cancer cell lines [132,135].

In addition to the protective effects of DIM against tumorigenesis, DIM has more effects in inhibiting chemotaxis and metastasis by inactivating of CXCR4 and CXCL12 at low concentrations by affecting AhR and ER in carcinogenesis [136]. The urokinase plasminogen activator (uPA) system is confirmed to have potential effects in cell migration, angiogenesis, cancer invasion and metastasis. Some studies have shown that DIM can downregulate uPA in the inhibition of tumor progression in prostate and breast cancer $[137,138]$. Furthermore, DIM inhibited cell proliferation, migration and metastasis by directly inactivating vascular endothelial growth factor (VEGF) and MMP and by involving the degradation of the basement membrane in original vessels, endothelial cell activation and migration [139].

DIM has been reported to repress tumor malignancy via inhibiting the EMT process. DIM deterred EMT in prostate cancer cells by blocking AR signaling and the expression of prostate-specific antigen (PSA), an AR-target gene, resulting in the reduction of the expression of EMT markers, ZEB1, N-cadherin and fibronectin [140]. DIM upregulated the protein expression of $E$-cadherin and downregulated the protein expression of vimentin by attenuating miR-92a and the NF- $\mathrm{B}$ receptor activator. The PI3K/Akt/mTOR/NF- $\mathrm{KB}$ signaling pathway has been known to induce migration, invasion and EMT. However, DIM reversed EMT by modulating the PI3K/Akt/mTOR/NF- $\mathrm{kB}$ signaling. DIM also decreased the expression of mesenchymal markers ZEB1, vimentin and Slug and changed the morphology of pancreatic cancer cells into the epithelial form [141,142].

Recently, miRNA has been shown to have a crucial role in the initiation, progression and metastasis of cancer, and DIM has been shown to function as miRNA regulators affecting cancer metastasis and growth by modulating EMT [143]. DIM can repair the miRNA deformity and inhibit the mutation of miRNA in vinyl carbamate-induced mouse lung cancer [144]. According to a recent study by Li et al., DIM treatment decreased the expression of vimentin, ZEB1 and Slug as EMT markers with reversal of EMT in pancreatic cancer cells via the increased expression of miR-200 [145]. DIM promoted the expression of the let-7 family, while it reversed the tumor progression and EMT by preventing ZEB1 [145], and it conducted the reduction of enhancer of zeste homolog 2 (EZH2) intervening in EMT phenotypic cells [146]. In a recent study, DIM also showed depression of miR-34a and inhibition of cancer growth via AR signaling in vivo [147]. In addition, DIM upregulated the protein expression of $E$-cadherin and downregulated the protein expression of vimentin by attenuating miR-92a and the NF- $\kappa B$ receptor activator [148]. In this way, DIM as an miRNA controller can lead to the repression of EMT and to a new therapy in prostate cancer.

Li et al. also demonstrated that DIM could be effective against pancreatic cancer by reversing the EMT phenomenon by upregulating the expression of miR-200 and the let-7 family, which are typically lost in many other cancers [145]. Wu et al. showed that DIM inhibited the metastasis of nasopharyngeal carcinoma (NPC) and EMT by promoting the expression of mesenchymal markers, Snail and Slug [149]. Moreover, DIM reversed E-cadherin expression in NPC, which experienced the EMT process, and DIM-induced E-cadherin expression has confirmed as having a significant positive correlation with the long-time outcome of NPC patients [150].

\section{Conclusions}

The phytoestrogens have generated considerable interests as alternatives for hormone replacement therapy (HRT) and chemopreventive compounds for recent years, because they have diverse bioactivities, low toxicity for the human body and easy acceptance as dietary supplements.

In the present study, we suggested significant roles of phytoestrogens in the inhibition of cancer progression via EMT, which is a crucial process inducing cancer migration, invasion and metastasis. Genistein, resveratrol, kaempferol and DIM have been evaluated to effectively repress the EMT process 
in diverse cancers by affecting the signaling pathways and the expression of EMT-related markers, as shown in the diagram of Figure 2. Specific signaling pathways and EMT markers regulated by genistein, resveratrol, kaempferol and DIM, are summarized in Table 1. In addition, since these phytoestrogens have been also reported to exert anti-carcinogenic effects by controlling cell cycle, cell proliferation and apoptosis in hormone-related, as well as non-hormone-related cancers, they may be considered as effective anti-cancer agents to inhibit the whole process of cancer progression.

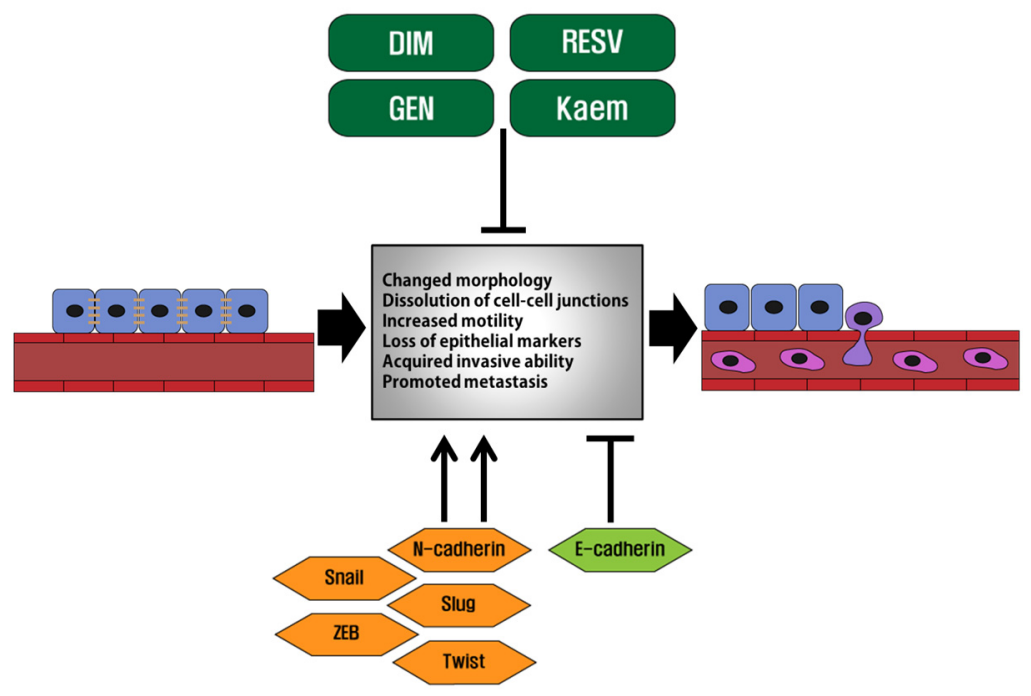

Figure 2. Schematic diagram of the EMT process and the roles of phytoestrogens, genistein, resveratrol, kaempferol and DIM, in the regulation of the EMT process in cancer metastasis. EMT plays a key role in tumor progression. The cells undergoing EMT show E-cadherin repression, but increased expression of EMT markers, such as Snail, Slug and vimentin, and cell motility-related proteins, including MMPs and uPA. As a result, they gain enhanced migration and invasion capabilities: primary cancer cells lose cell-cell adhesion, break through the basement membrane and enter the bloodstream through intravasation. Later, the circulating tumor cells exit the bloodstream to migrate to the specific metastatic sites, where they undergo MET for clonal outgrowth. On the other hand, genistein, resveratrol, kaempferol and DIM may inhibit cancer metastasis by repressing the EMT process through affecting the signaling pathways associated with EMT and regulating the expression of EMT markers.

Table 1. Potential signal transductions related to EMT targeted by dietary phytoestrogens.

\begin{tabular}{clc}
\hline Phytoestrogen & \multicolumn{1}{c}{ EMT-Related Signalings } & Reference \\
\hline Genistein & TGF- $\beta$, Smad, PI3K, Akt, NF-kB, Notch-1, MAPK, ER & {$[58,90,92]$} \\
\hline Resveratrol & Hedgehog, TGF- $\beta$, Smad, AKT, EGF & {$[107,108,110,111,113,114]$} \\
\hline Kaempferol & ER, AR, AhR, PR, TGF- $\beta$, Smad3, PI3K/Akt, RAF/ERK & {$[117-119,125,126,128]$} \\
\hline \multirow{2}{*}{ Diindolylmethane } & AR, PI3K/Akt/mTOR/NF-kB, Hedgehog, miR-200, & \multirow{2}{*}{ RANKL, $\beta$-catenin } \\
\hline
\end{tabular}

Nevertheless, controversies about the chemopreventive effect of phytoestrogens have existed because their cancer promoting effects have been also reported. Several phytoestrogens, including genistein and resveratrol, were known to have a biphasic effect, especially in hormone-dependent cancers: based on the specific concentration, cancer cell growth is stimulated at lower concentrations and inhibited at higher concentrations [19]. More skepticism regarding the chemopreventive effects of phytoestrogens came from the in vitro concentration of phytoestrogen being generally $10 \mu \mathrm{M}$, and plasma concentrations of $>10 \mu \mathrm{M}$ cannot be attainable by the dietary intake of phytoestrogen-containing food; thus, low levels of phytoestrogen, rather, may stimulate cancer growth. However, this insistence is still incompetent to abrogate the experimental and epidemiological evidence of phytoestrogens 
supporting anti-proliferative and anti-carcinogenic effects. Accordingly, more investigations of the relationship between the hazardous and chemopreventive effects of phytoestrogens in the body are needed at this stage. Besides, the poor bioavailability of phytoestrogens, such as resveratrol, in the body is another pitfall in the application of phytoestrogens, which has to be improved [97]. The toxicological issues posed by phytoestrogens also should be considered in their applications. For instance, the possibility that serum genistein concentrations found in soy-fed infants may induce thymic and immune abnormalities was raised [151]. High doses of genistein $(>5 \mu \mathrm{M})$ may act as a topoisomerase II inhibitor and a DNA damaging genotoxin [152]. Genistein was reported to be capable of altering the toxicological behaviors of the endocrine-active pesticide methoxychlor and likely other endocrine-active compounds, as well [153]. In this way, the adverse effects of phytoestrogens on normal cellular function have been found. As with many other compounds, there are many pros and cons associated with phytoestrogens, and thus, it is urgently needed to shape the development of guidelines for the use of phytoestrogens for maximizing health benefits, as well as minimizing the adverse effects [154].

From this review, we may suggest that phytoestrogens are potent compounds that abrogate the cell migration, invasion and metastasis of cancer by effectively suppressing the EMT process. Phytoestrogen treatments are a promising way to prevent cancer development as safer alternatives for the natural strategies against cancers, though we need more research and interest for going forward to clinical trials.

Acknowledgments: This work was supported by a National Research Foundation of Korea (NRF) grant funded by the Ministry of Education, Science and Technology (MEST) of the Republic of Korea (2014R1A1A2055295). This work was supported by a grant from the Next-Generation BioGreen 21 Program (No. PJ011355-2015), Rural Development Administration, Republic of Korea.

Conflicts of Interest: None of the authors have any conflicts of interest to declare.

\section{References}

1. Cragg, G.M.; Grothaus, P.G.; Newman, D.J. Impact of natural products on developing new anti-cancer agents. Chem. Rev. 2009, 109, 3012-3043. [CrossRef] [PubMed]

2. Fitter, A. Ecology. Making allelopathy respectable. Science 2003, 301, 1337-1338. [CrossRef] [PubMed]

3. Acharya, A.; Das, I.; Singh, S.; Saha, T. Chemopreventive properties of indole-3-carbinol, diindolylmethane and other constituents of cardamom against carcinogenesis. Recent Pat. Food Nutr. Agric. 2010, 2, 166-177. [CrossRef] [PubMed]

4. Sporn, M.B.; Suh, N. Chemoprevention of cancer. Carcinogenesis 2000, 21, 525-530. [CrossRef] [PubMed]

5. Cragg, G.M.; Newman, D.J. Plants as a source of anti-cancer agents. J. Ethnopharmacol. 2005, 100, 72-79. [CrossRef] [PubMed]

6. Thakur, V.S.; Deb, G.; Babcook, M.A.; Gupta, S. Plant phytochemicals as epigenetic modulators: Role in cancer chemoprevention. AAPS J. 2014, 16, 151-163. [CrossRef] [PubMed]

7. Allred, K.F.; Yackley, K.M.; Vanamala, J.; Allred, C.D. Trigonelline is a novel phytoestrogen in coffee beans. J. Nutr. 2009, 139, 1833-1838. [CrossRef] [PubMed]

8. Santen, R.J.; Boyd, N.F.; Chlebowski, R.T.; Cummings, S.; Cuzick, J.; Dowsett, M.; Easton, D.; Forbes, J.F.; Key, T.; Hankinson, S.E.; et al. Critical assessment of new risk factors for breast cancer: Considerations for development of an improved risk prediction model. Endocr. Relat. Cancer 2007, 14, 169-187. [CrossRef] [PubMed]

9. Giacalone, P.L.; Daures, J.P.; Ouafik, L.; Martin, P.M.; Laffargue, F.; Maudelonde, T. Steroids and adrenomedullin growth patterns in human ovarian cancer cells: Estrogenic-regulation assay. Gynecol. Oncol. 2003, 91, 651-656. [CrossRef]

10. Chung, S.H.; Franceschi, S.; Lambert, P.F. Estrogen and ERalpha: Culprits in cervical cancer? Trends Endocrinol. Metab. 2010, 21, 504-511. [CrossRef] [PubMed]

11. Hwang, K.A.; Kang, N.H.; Yi, B.R.; Lee, H.R.; Park, M.A.; Choi, K.C. Genistein, a soy phytoestrogen, prevents the growth of BG-1 ovarian cancer cells induced by 17beta-estradiol or bisphenol A via the inhibition of cell cycle progression. Int. J. Oncol. 2013, 42, 733-740. [PubMed] 
12. Ahn, H.N.; Jeong, S.Y.; Bae, G.U.; Chang, M.; Zhang, D.; Liu, X.; Pei, Y.; Chin, Y.W.; Lee, J.; Oh, S.R.; et al. Selective estrogen receptor modulation by larrea nitida on MCF-7 Cell proliferation and immature rat uterus. Biomol. Ther. 2014, 22, 347-354. [CrossRef] [PubMed]

13. Shang, Y.; Brown, M. Molecular determinants for the tissue specificity of SERMs. Science 2002, 295, 2465-2468. [CrossRef] [PubMed]

14. Kuiper, G.G.; Lemmen, J.G.; Carlsson, B.; Corton, J.C.; Safe, S.H.; van der Saag, P.T.; van der Burg, B.; Gustafsson, J.A. Interaction of estrogenic chemicals and phytoestrogens with estrogen receptor beta. Endocrinology 1998, 139, 4252-4263. [PubMed]

15. Zhao, E.; Mu, Q. Phytoestrogen biological actions on Mammalian reproductive system and cancer growth. Sci. Pharm. 2011, 79, 1-20. [CrossRef] [PubMed]

16. Harris, D.M.; Besselink, E.; Henning, S.M.; Go, V.L.; Heber, D. Phytoestrogens induce differential estrogen receptor alpha- or Beta-mediated responses in transfected breast cancer cells. Exp. Biol. Med. 2005, 230, 558-568.

17. Hsieh, C.Y.; Santell, R.C.; Haslam, S.Z.; Helferich, W.G. Estrogenic effects of genistein on the growth of estrogen receptor-positive human breast cancer (MCF-7) cells in vitro and in vivo. Cancer Res. 1998, 58, 3833-3838. [PubMed]

18. Ju, Y.H.; Fultz, J.; Allred, K.F.; Doerge, D.R.; Helferich, W.G. Effects of dietary daidzein and its metabolite, equol, at physiological concentrations on the growth of estrogen-dependent human breast cancer (MCF-7) tumors implanted in ovariectomized athymic mice. Carcinogenesis 2006, 27, 856-863. [CrossRef] [PubMed]

19. Magee, P.J.; Rowland, I.R. Phyto-oestrogens, their mechanism of action: Current evidence for a role in breast and prostate cancer. Br. J. Nutr. 2004, 91, 513-531. [CrossRef] [PubMed]

20. Rice, S.; Whitehead, S.A. Phytoestrogens and breast cancer-Promoters or protectors? Endocr. Relat. Cancer 2006, 13, 995-1015. [CrossRef] [PubMed]

21. Kirk, C.J.; Harris, R.M.; Wood, D.M.; Waring, R.H.; Hughes, P.J. Do dietary phytoestrogens influence susceptibility to hormone-dependent cancer by disrupting the metabolism of endogenous oestrogens? Biochem. Soc. Trans. 2001, 29, 209-216. [CrossRef] [PubMed]

22. Labrie, F.; Luu-The, V.; Lin, S.X.; Labrie, C.; Simard, J.; Breton, R.; Belanger, A. The key role of $17 \beta$-hydroxysteroid dehydrogenases in sex steroid biology. Steroids 1997, 62, 148-158. [CrossRef]

23. Murkies, A.L.; Wilcox, G.; Davis, S.R. Clinical review 92, Phytoestrogens. J. Clin. Endocrinol. Metab. 1998, 83, 297-303. [PubMed]

24. Pilsakova, L.; Riecansky, I.; Jagla, F. The physiological actions of isoflavone phytoestrogens. Physiol. Res. 2010, 59, 651-664. [PubMed]

25. Hutchins, A.M.; Lampe, J.W.; Martini, M.C.; Campbell, D.R.; Slavin, J.L. Vegetables, fruits, and legumes: Effect on urinary isoflavonoid phytoestrogen and lignan excretion. J. Am. Diet. Assoc. 1995, 95, 769-774. [CrossRef]

26. Milder, I.E.; Arts, I.C.; van de Putte, B.; Venema, D.P.; Hollman, P.C. Lignan contents of Dutch plant foods: A database including lariciresinol, pinoresinol, secoisolariciresinol and matairesinol. Br. J. Nutr. 2005, 93, 393-402. [CrossRef] [PubMed]

27. Zamora-Ros, R.; Knaze, V.; Lujan-Barroso, L.; Kuhnle, G.G.; Mulligan, A.A.; Touillaud, M.; Slimani, N.; Romieu, I.; Powell, N.; Tumino, R.; et al. Dietary intakes and food sources of phytoestrogens in the European Prospective Investigation into Cancer and Nutrition (EPIC) 24-h dietary recall cohort. Eur. J. Clin. Nutr. 2012, 66, 932-941. [CrossRef] [PubMed]

28. Heinonen, S.; Nurmi, T.; Liukkonen, K.; Poutanen, K.; Wahala, K.; Deyama, T.; Nishibe, S.; Adlercreutz, H. In vitro metabolism of plant lignans: New precursors of mammalian lignans enterolactone and enterodiol. J. Agric. Food Chem. 2001, 49, 3178-3186. [CrossRef] [PubMed]

29. Boker, L.K.; Van der Schouw, Y.T.; De Kleijn, M.J.; Jacques, P.F.; Grobbee, D.E.; Peeters, P.H. Intake of dietary phytoestrogens by Dutch women. J. Nutr. 2002, 132, 1319-1328. [PubMed]

30. Manjanatha, M.; Shelton, S.; Bishop, M.; Lyn-Cook, L.; Aidoo, A. Dietary effects of soy isoflavones daidzein and genistein on 7,12-dimethylbenz[a]anthracene-induced mammary mutagenesis and carcinogenesis in ovariectomized Big Blue transgenic rats. Carcinogenesis 2006, 27, 1970-1979. [CrossRef] [PubMed]

31. Sobolev, V.S.; Horn, B.W.; Potter, T.L.; Deyrup, S.T.; Gloer, J.B. Production of stilbenoids and phenolic acids by the peanut plant at early stages of growth. J. Agric. Food Chem. 2006, 54, 3505-3511. [CrossRef] [PubMed]

32. Jang, M.; Cai, L.; Udeani, G.O.; Slowing, K.V.; Thomas, C.F.; Beecher, C.W.; Fong, H.H.; Farnsworth, N.R.; Kinghorn, A.D.; Mehta, R.G.; et al. Cancer chemopreventive activity of resveratrol, a natural product derived from grapes. Science 1997, 275, 218-220. [CrossRef] [PubMed] 
33. Heerboth, S.; Housman, G.; Leary, M.; Longacre, M.; Byler, S.; Lapinska, K.; Willbanks, A.; Sarkar, S. EMT and tumor metastasis. Clin. Transl. Med. 2015, 4. [CrossRef] [PubMed]

34. Spano, D.; Heck, C.; De Antonellis, P.; Christofori, G.; Zollo, M. Molecular networks that regulate cancer metastasis. Semin. Cancer Biol. 2012, 22, 234-249. [CrossRef] [PubMed]

35. Siegel, R.L.; Miller, K.D.; Jemal, A. Cancer statistics, 2016. CA Cancer J. Clin. 2016, 66, 7-30. [CrossRef] [PubMed]

36. Voulgari, A.; Pintzas, A. Epithelial-mesenchymal transition in cancer metastasis: Mechanisms, markers and strategies to overcome drug resistance in the clinic. Biochim. Biophys. Acta 2009, 1796, 75-90. [CrossRef] [PubMed]

37. Hanahan, D.; Weinberg, R.A. The hallmarks of cancer. Cell 2000, 100, 57-70. [CrossRef]

38. Yap, A.S.; Brieher, W.M.; Gumbiner, B.M. Molecular and functional analysis of cadherin-based adherens junctions. Annu. Rev. Cell Dev. Biol. 1997, 13, 119-146. [CrossRef] [PubMed]

39. Onder, T.T.; Gupta, P.B.; Mani, S.A.; Yang, J.; Lander, E.S.; Weinberg, R.A. Loss of E-cadherin promotes metastasis via multiple downstream transcriptional pathways. Cancer Res. 2008, 68, 3645-3654. [CrossRef] [PubMed]

40. Boyer, B.; Thiery, J.P. Epithelium-mesenchyme interconversion as example of epithelial plasticity. APMIS 1993, 101, 257-268. [CrossRef] [PubMed]

41. Thiery, J.P. Cell adhesion in development: A complex signaling network. Curr. Opin. Genet. Dev. 2003, 13, 365-371. [CrossRef]

42. Miyoshi, J.; Takai, Y. Structural and functional associations of apical junctions with cytoskeleton. Biochim. Biophys. Acta 2008, 1778, 670-691. [CrossRef] [PubMed]

43. Yang, J.; Weinberg, R.A. Epithelial-mesenchymal transition: At the crossroads of development and tumor metastasis. Dev. Cell 2008, 14, 818-829. [CrossRef] [PubMed]

44. Friedl, P.; Wolf, K. Tumour-cell invasion and migration: Diversity and escape mechanisms. Nat. Rev. Cancer 2003, 3, 362-374. [CrossRef] [PubMed]

45. Polette, M.; Nawrocki-Raby, B.; Gilles, C.; Clavel, C.; Birembaut, P. Tumour invasion and matrix metalloproteinases. Crit. Rev. Oncol. Hematol. 2004, 49, 179-186. [CrossRef] [PubMed]

46. Son, H.; Moon, A. Epithelial-mesenchymal Transition and Cell Invasion. Toxicol. Res. 2010, 26, $245-252$. [CrossRef] [PubMed]

47. Davies, J.A. Mesenchyme to epithelium transition during development of the mammalian kidney tubule. Acta Anat. 1996, 156, 187-201. [CrossRef] [PubMed]

48. Foroni, C.; Broggini, M.; Generali, D.; Damia, G. Epithelial-mesenchymal transition and breast cancer: Role, molecular mechanisms and clinical impact. Cancer Treat. Rev. 2012, 38, 689-697. [CrossRef] [PubMed]

49. Chaffer, C.L.; Weinberg, R.A. A perspective on cancer cell metastasis. Science 2011, 331, 1559-1564. [CrossRef] [PubMed]

50. Perl, A.K.; Wilgenbus, P.; Dahl, U.; Semb, H.; Christofori, G. A causal role for E-cadherin in the transition from adenoma to carcinoma. Nature 1998, 392, 190-193. [CrossRef] [PubMed]

51. Thiery, J.P.; Sleeman, J.P. Complex networks orchestrate epithelial-mesenchymal transitions. Nat. Rev. Mol. Cell Biol. 2006, 7, 131-142. [CrossRef] [PubMed]

52. Bailey, J.M.; Singh, P.K.; Hollingsworth, M.A. Cancer metastasis facilitated by developmental pathways: Sonic hedgehog, Notch, and bone morphogenic proteins. J. Cell. Biochem. 2007, 102, 829-839. [CrossRef] [PubMed]

53. Zeisberg, M.; Neilson, E.G. Biomarkers for epithelial-mesenchymal transitions. J. Clin. Investig. 2009, 119, 1429-1437. [CrossRef] [PubMed]

54. Batlle, E.; Sancho, E.; Franci, C.; Dominguez, D.; Monfar, M.; Baulida, J.; Garcia De Herreros, A. The transcription factor snail is a repressor of $E$-cadherin gene expression in epithelial tumour cells. Nat. Cell Biol. 2000, 2, 84-89. [CrossRef] [PubMed]

55. Yang, M.H.; Wu, M.Z.; Chiou, S.H.; Chen, P.M.; Chang, S.Y.; Liu, C.J.; Teng, S.C.; Wu, K.J. Direct regulation of TWIST by HIF-1alpha promotes metastasis. Nat. Cell Biol. 2008, 10, 295-305. [CrossRef] [PubMed]

56. Thiery, J.P. Epithelial-mesenchymal transitions in development and pathologies. Curr. Opin. Cell Biol. 2003, 15, 740-746. [CrossRef] [PubMed]

57. Bani-Hani, A.H.; Campbell, M.T.; Meldrum, D.R.; Meldrum, K.K. Cytokines in epithelial-mesenchymal transition: A new insight into obstructive nephropathy. J. Urol. 2008, 180, 461-468. [CrossRef] [PubMed] 
58. Han, L.; Zhang, H.W.; Zhou, W.P.; Chen, G.M.; Guo, K.J. The effects of genistein on transforming growth factor-beta1-induced invasion and metastasis in human pancreatic cancer cell line Panc-1 in vitro. Chin. Med. J. 2012, 125, 2032-2040. [PubMed]

59. Zhang, Y.E. Non-Smad pathways in TGF- $\beta$ signaling. Cell Res. 2009, 19, 128-139. [CrossRef] [PubMed]

60. Bertran, E.; Crosas-Molist, E.; Sancho, P.; Caja, L.; Lopez-Luque, J.; Navarro, E.; Egea, G.; Lastra, R.; Serrano, T.; Ramos, E.; et al. Overactivation of the TGF- $\beta$ pathway confers a mesenchymal-like phenotype and CXCR4-dependent migratory properties to liver tumor cells. Hepatology 2013, 58, 2032-2044. [CrossRef] [PubMed]

61. Hu, T.H.; Yao, Y.; Yu, S.; Han, L.L.; Wang, W.J.; Guo, H.; Tian, T.; Ruan, Z.P.; Kang, X.M.; Wang, J.; et al. SDF-1/CXCR4 promotes epithelial-mesenchymal transition and progression of colorectal cancer by activation of the Wnt/beta-catenin signaling pathway. Cancer Lett. 2014, 354, 417-426. [CrossRef] [PubMed]

62. Gitler, A.D.; Lu, M.M.; Jiang, Y.Q.; Epstein, J.A.; Gruber, P.J. Molecular markers of cardiac endocardial cushion development. Dev. Dyn. 2003, 228, 643-650. [CrossRef] [PubMed]

63. Liebner, S.; Cattelino, A.; Gallini, R.; Rudini, N.; Iurlaro, M.; Piccolo, S.; Dejana, E. $\beta$-catenin is required for endothelial-mesenchymal transformation during heart cushion development in the mouse. J. Cell Biol. 2004, 166, 359-367. [CrossRef] [PubMed]

64. Wang, Z.; Banerjee, S.; Li, Y.; Rahman, K.M.; Zhang, Y.; Sarkar, F.H. Down-regulation of notch-1 inhibits invasion by inactivation of nuclear factor-kappaB, vascular endothelial growth factor, and matrix metalloproteinase-9 in pancreatic cancer cells. Cancer Res. 2006, 66, 2778-2784. [CrossRef] [PubMed]

65. Miyamoto, Y.; Maitra, A.; Ghosh, B.; Zechner, U.; Argani, P.; Iacobuzio-Donahue, C.A.; Sriuranpong, V.; Iso, T.; Meszoely, I.M.; Wolfe, M.S.; et al. Notch mediates TGF alpha-induced changes in epithelial differentiation during pancreatic tumorigenesis. Cancer Cell 2003, 3, 565-576. [CrossRef]

66. Shao, S.; Zhao, X.; Zhang, X.; Luo, M.; Zuo, X.; Huang, S.; Wang, Y.; Gu, S.; Zhao, X. Notch1 signaling regulates the epithelial-mesenchymal transition and invasion of breast cancer in a Slug-dependent manner. Mol. Cancer 2015, 14, 28. [CrossRef] [PubMed]

67. Thayer, S.P.; di Magliano, M.P.; Heiser, P.W.; Nielsen, C.M.; Roberts, D.J.; Lauwers, G.Y.; Qi, Y.P.; Gysin, S.; Fernandez-del Castillo, C.; Yajnik, V.; et al. Hedgehog is an early and late mediator of pancreatic cancer tumorigenesis. Nature 2003, 425, 851-856. [CrossRef] [PubMed]

68. Yoo, Y.A.; Kang, M.H.; Lee, H.J.; Kim, B.H.; Park, J.K.; Kim, H.K.; Kim, J.S.; Oh, S.C. Sonic hedgehog pathway promotes metastasis and lymphangiogenesis via activation of Akt, EMT, and MMP-9 pathway in gastric cancer. Cancer Res. 2011, 71, 7061-7070. [CrossRef] [PubMed]

69. Gregory, R.I.; Chendrimada, T.P.; Cooch, N.; Shiekhattar, R. Human RISC couples microRNA biogenesis and posttranscriptional gene silencing. Cell 2005, 123, 631-640. [CrossRef] [PubMed]

70. Filipowicz, W.; Jaskiewicz, L.; Kolb, F.A.; Pillai, R.S. Post-transcriptional gene silencing by siRNAs and miRNAs. Curr. Opin. Struct. Biol. 2005, 15, 331-341. [CrossRef] [PubMed]

71. Siemens, H.; Jackstadt, R.; Hunten, S.; Kaller, M.; Menssen, A.; Gotz, U.; Hermeking, H. miR-34 and SNAIL form a double-negative feedback loop to regulate epithelial-mesenchymal transitions. Cell Cycle 2011, 10, 4256-4271. [CrossRef] [PubMed]

72. Dahl, K.D.C.; Dahl, R.; Kruichak, J.N.; Hudson, L.G. The epidermal growth factor receptor responsive miR-125a represses mesenchymal morphology in ovarian cancer cells. Neoplasia 2009, 11, 1208-1215. [CrossRef]

73. Yang, D.; Sun, Y.; Hu, L.; Zheng, H.; Ji, P.; Pecot, C.V.; Zhao, Y.; Reynolds, S.; Cheng, H.; Rupaimoole, R.; et al. Integrated analyses identify a master microRNA regulatory network for the mesenchymal subtype in serous ovarian cancer. Cancer Cell 2013, 23, 186-199. [CrossRef] [PubMed]

74. Yeh, Y.M.; Chuang, C.M.; Chao, K.C.; Wang, L.H. MicroRNA-138 suppresses ovarian cancer cell invasion and metastasis by targeting SOX4 and HIF-1alpha. Int. J. Cancer 2013, 133, 867-878. [CrossRef] [PubMed]

75. Cheng, C.W.; Wang, H.W.; Chang, C.W.; Chu, H.W.; Chen, C.Y.; Yu, J.C.; Chao, J.I.; Liu, H.F.; Ding, S.L.; Shen, C.Y. MicroRNA-30a inhibits cell migration and invasion by downregulating vimentin expression and is a potential prognostic marker in breast cancer. Breast Cancer Res. Treat. 2012, 134, 1081-1093. [CrossRef] [PubMed]

76. Kumarswamy, R.; Mudduluru, G.; Ceppi, P.; Muppala, S.; Kozlowski, M.; Niklinski, J.; Papotti, M.; Allgayer, H. MicroRNA-30a inhibits epithelial-to-mesenchymal transition by targeting Snai1 and is downregulated in non-small cell lung cancer. Int. J. Cancer 2012, 130, 2044-2053. [CrossRef] [PubMed] 
77. Liu, Z.; Gersbach, E.; Zhang, X.; Xu, X.; Dong, R.; Lee, P.; Liu, J.; Kong, B.; Shao, C.; Wei, J.J. miR-106a represses the $\mathrm{Rb}$ tumor suppressor $\mathrm{p} 130$ to regulate cellular proliferation and differentiation in high-grade serous ovarian carcinoma. Mol. Cancer Res. 2013, 11, 1314-1325. [CrossRef] [PubMed]

78. Ma, L.; Teruya-Feldstein, J.; Weinberg, R.A. Tumour invasion and metastasis initiated by microRNA-10b in breast cancer. Nature 2007, 449, 682-688. [CrossRef] [PubMed]

79. Zhang, L.; Sun, J.; Wang, B.; Ren, J.C.; Su, W.; Zhang, T. MicroRNA-10b triggers the Epithelial-Mesenchymal Transition (EMT) of laryngeal carcinoma Hep-2 cells by directly targeting the E-cadherin. Appl. Biochem. Biotechnol. 2015, 176, 33-44. [CrossRef] [PubMed]

80. Gregory, P.A.; Bert, A.G.; Paterson, E.L.; Barry, S.C.; Tsykin, A.; Farshid, G.; Vadas, M.A.; Khew-Goodall, Y.; Goodall, G.J. The miR-200 family and miR-205 regulate epithelial to mesenchymal transition by targeting ZEB1 and SIP1. Nat. Cell Biol. 2008, 10, 593-601. [CrossRef] [PubMed]

81. Korpal, M.; Lee, E.S.; Hu, G.; Kang, Y. The miR-200 family inhibits epithelial-mesenchymal transition and cancer cell migration by direct targeting of E-cadherin transcriptional repressors ZEB1 and ZEB2. J. Biol. Chem. 2008, 283, 14910-14914. [CrossRef] [PubMed]

82. Dykxhoorn, D.M. MicroRNAs and metastasis: Little RNAs go a long way. Cancer Res. 2010, 70, 6401-6406. [CrossRef] [PubMed]

83. Guarino, M. Epithelial-mesenchymal transition and tumour invasion. Int. J. Biochem. Cell Biol. 2007, 39, $2153-2160$. [CrossRef] [PubMed]

84. Kim, S.H.; Kim, C.W.; Jeon, S.Y.; Go, R.E.; Hwang, K.A.; Choi, K.C. Chemopreventive and chemotherapeutic effects of genistein, a soy isoflavone, upon cancer development and progression in preclinical animal models. Lab. Anim. Res. 2014, 30, 143-150. [CrossRef] [PubMed]

85. Perabo, F.G.; Von Low, E.C.; Ellinger, J.; von Rucker, A.; Muller, S.C.; Bastian, P.J. Soy isoflavone genistein in prevention and treatment of prostate cancer. Prostate Cancer Prostatic Dis. 2008, 11, 6-12. [CrossRef] [PubMed]

86. Huang, J.; Nasr, M.; Kim, Y.; Matthews, H.R. Genistein inhibits protein histidine kinase. J. Biol. Chem. 1992, 267, 15511-15515. [PubMed]

87. Ju, Y.H.; Allred, K.F.; Allred, C.D.; Helferich, W.G. Genistein stimulates growth of human breast cancer cells in a novel, postmenopausal animal model, with low plasma estradiol concentrations. Carcinogenesis 2006, 27, 1292-1299. [CrossRef] [PubMed]

88. Pelekanou, V.; Leclercq, G. Recent insights into the effect of natural and environmental estrogens on mammary development and carcinogenesis. Int. J. Dev. Biol. 2011, 55, 869-878. [CrossRef] [PubMed]

89. Pavese, J.M.; Farmer, R.L.; Bergan, R.C. Inhibition of cancer cell invasion and metastasis by genistein. Cancer Metastasis Rev. 2010, 29, 465-482. [CrossRef] [PubMed]

90. Bao, B.; Wang, Z.; Ali, S.; Kong, D.; Li, Y.; Ahmad, A.; Banerjee, S.; Azmi, A.S.; Miele, L.; Sarkar, F.H. Notch-1 induces epithelial-mesenchymal transition consistent with cancer stem cell phenotype in pancreatic cancer cells. Cancer Lett. 2011, 307, 26-36. [CrossRef] [PubMed]

91. Kim, A.Y.; Kwak, J.H.; Je, N.K.; Lee, Y.H.; Jung, Y.S. Epithelial-mesenchymal transition is associated with acquired resistance to 5-Fluorocuracil in HT-29 colon cancer cells. Toxicol. Res. 2015, 31, 151-156. [CrossRef] [PubMed]

92. Kim, Y.S.; Choi, K.C.; Hwang, K.A. Genistein suppressed epithelial-mesenchymal transition and migration efficacies of BG-1 ovarian cancer cells activated by estrogenic chemicals via estrogen receptor pathway and downregulation of TGF-beta signaling pathway. Phytomedicine 2015, 22, 993-999. [CrossRef] [PubMed]

93. Dai, W.; Wang, F.; He, L.; Lin, C.; Wu, S.; Chen, P.; Zhang, Y.; Shen, M.; Wu, D.; Wang, C.; et al. Genistein inhibits hepatocellular carcinoma cell migration by reversing the epithelial-mesenchymal transition: Partial mediation by the transcription factor NFAT1. Mol. Carcinog. 2015, 54, 301-311. [CrossRef] [PubMed]

94. Liu, J.F.; Zhao, S.H.; Wu, S.S. Depleting NFAT1 expression inhibits the ability of invasion and migration of human lung cancer cells. Cancer Cell Int. 2013, 13, 41. [CrossRef] [PubMed]

95. Zhang, L.L.; Li, L.; Wu, D.P.; Fan, J.H.; Li, X.; Wu, K.J.; Wang, X.Y.; He, D.L. A novel anti-cancer effect of genistein: Reversal of epithelial mesenchymal transition in prostate cancer cells. Acta Pharmacol. Sin. 2008, 29, 1060-1068. [CrossRef] [PubMed]

96. Nonomura, S.; Kanagawa, H.; Makimoto, A. Chemical Constituents of Polygonaceous Plants. I. Studies on the Components of Ko-J O-Kon. (Polygonum Cuspidatum Sieb. Et Zucc.). J. Pharm. Soc. Jpn. 1963, 83, 988-990.

97. Carter, L.G.; D’Orazio, J.A.; Pearson, K.J. Resveratrol and cancer: Focus on in vivo evidence. Endocr. Relat. Cancer 2014, 21, R209-R225. [CrossRef] [PubMed] 
98. Fremont, L. Biological effects of resveratrol. Life Sci. 2000, 66, 663-673. [CrossRef]

99. Adrian, M.; Rajaei, H.; Jeandet, P.; Veneau, J.; Bessis, R. Resveratrol oxidation in botrytis cinerea conidia. Phytopathology 1998, 88, 472-476. [CrossRef] [PubMed]

100. Ashby, J.; Tinwell, H.; Pennie, W.; Brooks, A.N.; Lefevre, P.A.; Beresford, N.; Sumpter, J.P. Partial and weak oestrogenicity of the red wine constituent resveratrol: Consideration of its superagonist activity in MCF-7 cells and its suggested cardiovascular protective effects. J. Appl. Toxicol. 1999, 19, 39-45. [CrossRef]

101. Bowers, J.L.; Tyulmenkov, V.V.; Jernigan, S.C.; Klinge, C.M. Resveratrol acts as a mixed agonist/antagonist for estrogen receptors alpha and beta. Endocrinology 2000, 141, 3657-3667. [PubMed]

102. Le Corre, L.; Chalabi, N.; Delort, L.; Bignon, Y.J.; Bernard-Gallon, D.J. Resveratrol and breast cancer chemoprevention: Molecular mechanisms. Mol. Nutr. Food Res. 2005, 49, 462-471. [CrossRef] [PubMed]

103. Mitchell, S.H.; Zhu, W.; Young, C.Y. Resveratrol inhibits the expression and function of the androgen receptor in LNCaP prostate cancer cells. Cancer Res. 1999, 59, 5892-5895. [PubMed]

104. Pervaiz, S. Resveratrol: From grapevines to mammalian biology. FASEB J. 2003, 17, 1975-1985. [CrossRef] [PubMed]

105. Leone, L.; Mazzetta, F.; Martinelli, D.; Valente, S.; Alimandi, M.; Raffa, S.; Santino, I. Klebsiella pneumoniae Is Able to Trigger Epithelial-Mesenchymal Transition Process in Cultured Airway Epithelial Cells. PLoS ONE 2016, 11, e0146365. [CrossRef] [PubMed]

106. Sun, Y.; Wang, H.; Liu, M.; Lin, F.; Hua, J. Resveratrol abrogates the effects of hypoxia on cell proliferation, invasion and EMT in osteosarcoma cells through downregulation of the HIF-1 $\alpha$ protein. Mol. Med. Rep. 2015, 11, 1975-1981. [CrossRef] [PubMed]

107. Li, W.; Cao, L.; Chen, X.; Lei, J.; Ma, Q. Resveratrol inhibits hypoxia-driven ROS-induced invasive and migratory ability of pancreatic cancer cells via suppression of the Hedgehog signaling pathway. Oncol. Rep. 2016, 35, 1718-1726. [CrossRef] [PubMed]

108. Gao, Q.; Yuan, Y.; Gan, H.Z.; Peng, Q. Resveratrol inhibits the hedgehog signaling pathway and epithelial-mesenchymal transition and suppresses gastric cancer invasion and metastasis. Oncol. Lett. 2015, 9, 2381-2387. [CrossRef] [PubMed]

109. Li, J.; Chong, T.; Wang, Z.; Chen, H.; Li, H.; Cao, J.; Zhang, P.; Li, H. A novel anticancer effect of resveratrol: Reversal of epithelialmesenchymal transition in prostate cancer cells. Mol. Med. Rep. 2014, 10, 1717-1724. [PubMed]

110. Ji, Q.; Liu, X.; Han, Z.; Zhou, L.; Sui, H.; Yan, L.; Jiang, H.; Ren, J.; Cai, J.; Li, Q. Resveratrol suppresses epithelial-to-mesenchymal transition in colorectal cancer through TGF- $\beta 1 /$ Smads signaling pathway mediated Snail/E-cadherin expression. BMC Cancer 2015, 15, 97. [CrossRef] [PubMed]

111. Xu, Q.; Zong, L.; Chen, X.; Jiang, Z.; Nan, L.; Li, J.; Duan, W.; Lei, J.; Zhang, L.; Ma, J.; et al. Resveratrol in the treatment of pancreatic cancer. Ann. N. Y. Acad. Sci. 2015, 1348, 10-19. [CrossRef] [PubMed]

112. Li, C.W.; Xia, W.; Lim, S.O.; Hsu, J.L.; Huo, L.; Wu, Y.; Li, L.Y.; Lai, C.C.; Chang, S.S.; Hsu, Y.H.; et al. AKT1 inhibits epithelial-to-mesenchymal transition in breast cancer through phosphorylation-dependent Twist1 degradation. Cancer Res. 2016. [CrossRef] [PubMed]

113. Vergara, D.; Valente, C.M.; Tinelli, A.; Siciliano, C.; Lorusso, V.; Acierno, R.; Giovinazzo, G.; Santino, A.; Storelli, C.; Maffia, M. Resveratrol inhibits the epidermal growth factor-induced epithelial mesenchymal transition in MCF-7 cells. Cancer Lett. 2011, 310, 1-8. [CrossRef] [PubMed]

114. Wang, H.; Zhang, H.; Tang, L.; Chen, H.; Wu, C.; Zhao, M.; Yang, Y.; Chen, X.; Liu, G. Resveratrol inhibits TGF- $\beta 1$-induced epithelial-to-mesenchymal transition and suppresses lung cancer invasion and metastasis. Toxicology 2013, 303, 139-146. [CrossRef] [PubMed]

115. Calderon-Montano, J.M.; Burgos-Moron, E.; Perez-Guerrero, C.; Lopez-Lazaro, M. A review on the dietary flavonoid kaempferol. Mini Rev. Med. Chem. 2011, 11, 298-344. [CrossRef] [PubMed]

116. Huang, L.; Yagura, T.; Chen, S. Sedative activity of hexane extract of Keampferia galanga L. and its active compounds. J. Ethnopharmacol. 2008, 120, 123-125. [CrossRef] [PubMed]

117. Boam, T. Anti-androgenic effects of flavonols in prostate cancer. Ecancermedicalscience 2015, 9, 585. [CrossRef] [PubMed]

118. Puppala, D.; Gairola, C.G.; Swanson, H.I. Identification of kaempferol as an inhibitor of cigarette smoke-induced activation of the aryl hydrocarbon receptor and cell transformation. Carcinogenesis 2007, 28, 639-647. [CrossRef] [PubMed] 
119. Toh, M.F.; Mendonca, E.; Eddie, S.L.; Endsley, M.P.; Lantvit, D.D.; Petukhov, P.A.; Burdette, J.E. Kaempferol exhibits progestogenic effects in ovariectomized rats. J. Steroids Horm. Sci. 2014, 5, 136. [PubMed]

120. Kang, J.W.; Kim, J.H.; Song, K.; Kim, S.H.; Yoon, J.H.; Kim, K.S. Kaempferol and quercetin, components of Ginkgo biloba extract (EGb 761), induce caspase-3-dependent apoptosis in oral cavity cancer cells. Phytother. Res. 2010, 24 (Suppl. S1), S77-S82. [CrossRef] [PubMed]

121. Niering, P.; Michels, G.; Watjen, W.; Ohler, S.; Steffan, B.; Chovolou, Y.; Kampkotter, A.; Proksch, P.; Kahl, R. Protective and detrimental effects of kaempferol in rat H4IIE cells: Implication of oxidative stress and apoptosis. Toxicol. Appl. Pharmacol. 2005, 209, 114-122. [CrossRef] [PubMed]

122. Samhan-Arias, A.K.; Martin-Romero, F.J.; Gutierrez-Merino, C. Kaempferol blocks oxidative stress in cerebellar granule cells and reveals a key role for reactive oxygen species production the plasma membrane in the commitment to apoptosis. Free Radic. Biol. Med. 2004, 37, 48-61. [CrossRef] [PubMed]

123. Leung, H.W.; Lin, C.J.; Hour, M.J.; Yang, W.H.; Wang, M.Y.; Lee, H.Z. Kaempferol induces apoptosis in human lung non-small carcinoma cells accompanied by an induction of antioxidant enzymes. Food Chem. Toxicol. 2007, 45, 2005-2013. [CrossRef] [PubMed]

124. Liou, A.K.; Clark, R.S.; Henshall, D.C.; Yin, X.M.; Chen, J. To die or not to die for neurons in ischemia, traumatic brain injury and epilepsy: A review on the stress-activated signaling pathways and apoptotic pathways. Prog. Neurobiol. 2003, 69, 103-142. [CrossRef]

125. Liang, S.Q.; Marti, T.M.; Dorn, P.; Froment, L.; Hall, S.R.; Berezowska, S.; Kocher, G.; Schmid, R.A.; Peng, R.W. Blocking the epithelial-to-mesenchymal transition pathway abrogates resistance to anti-folate chemotherapy in lung cancer. Cell Death Dis. 2015, 6, e1824. [CrossRef] [PubMed]

126. Jo, E.; Park, S.J.; Choi, Y.S.; Jeon, W.K.; Kim, B.C. Kaempferol suppresses transforming growth factor- $\beta 1$-Induced epithelial-to-mesenchymal transition and migration of A549 lung cancer cells by inhibiting Akt1-mediated phosphorylation of Smad3 at Threonine-179. Neoplasia 2015, 17, 525-537. [CrossRef] [PubMed]

127. Gong, J.H.; Cho, I.H.; Shin, D.; Han, S.Y.; Park, S.H.; Kang, Y.H. Inhibition of airway epithelial-to-mesenchymal transition and fibrosis by kaempferol in endotoxin-induced epithelial cells and ovalbumin-sensitized mice. Lab. Investig. 2014, 94, 297-308. [CrossRef] [PubMed]

128. Sulzmaier, F.J.; Ramos, J.W. RSK isoforms in cancer cell invasion and metastasis. Cancer Res. 2013, 73, 6099-6105. [CrossRef] [PubMed]

129. Anderton, M.J.; Manson, M.M.; Verschoyle, R.D.; Gescher, A.; Lamb, J.H.; Farmer, P.B.; Steward, W.P.; Williams, M.L. Pharmacokinetics and tissue disposition of indole-3-carbinol and its acid condensation products after oral administration to mice. Clin. Cancer Res. 2004, 10, 5233-5241. [CrossRef] [PubMed]

130. Banerjee, S.; Kong, D.; Wang, Z.; Bao, B.; Hillman, G.G.; Sarkar, F.H. Attenuation of multi-targeted proliferation-linked signaling by 3,3'-diindolylmethane (DIM): From bench to clinic. Mutat. Res. 2011, 728, 47-66. [CrossRef] [PubMed]

131. Marques, M.; Laflamme, L.; Benassou, I.; Cissokho, C.; Guillemette, B.; Gaudreau, L. Low levels of $3,3^{\prime}$-diindolylmethane activate estrogen receptor alpha and induce proliferation of breast cancer cells in the absence of estradiol. BMC Cancer 2014, 14, 524. [CrossRef] [PubMed]

132. Gong, Y.; Sohn, H.; Xue, L.; Firestone, G.L.; Bjeldanes, L.F. 3,3'-Diindolylmethane is a novel mitochondrial $\mathrm{H}(+)$-ATP synthase inhibitor that can induce p21(Cip1/Waf1) expression by induction of oxidative stress in human breast cancer cells. Cancer Res. 2006, 66, 4880-4887. [CrossRef] [PubMed]

133. Hong, C.; Firestone, G.L.; Bjeldanes, L.F. Bcl-2 family-mediated apoptotic effects of 3,3'-diindolylmethane (DIM) in human breast cancer cells. Biochem. Pharmacol. 2002, 63, 1085-1097. [CrossRef]

134. Li, Y.; Chinni, S.R.; Sarkar, F.H. Selective growth regulatory and pro-apoptotic effects of DIM is mediated by AKT and NF-kappaB pathways in prostate cancer cells. Front. Biosci. 2005, 10, 236-243. [CrossRef] [PubMed]

135. Choi, H.J.; Lim do, Y.; Park, J.H. Induction of G1 and G2/M cell cycle arrests by the dietary compound 3,3'-diindolylmethane in HT-29 human colon cancer cells. BMC Gastroenterol. 2009, 9, 39. [CrossRef] [PubMed]

136. Hsu, E.L.; Chen, N.; Westbrook, A.; Wang, F.; Zhang, R.; Taylor, R.T.; Hankinson, O. CXCR4 and CXCL12 down-regulation: A novel mechanism for the chemoprotection of 3,3'-diindolylmethane for breast and ovarian cancers. Cancer Lett. 2008, 265, 113-123. [CrossRef] [PubMed]

137. Ahmad, A.; Kong, D.; Sarkar, S.H.; Wang, Z.; Banerjee, S.; Sarkar, F.H. Inactivation of uPA and its receptor uPAR by $3,3^{\prime}$-diindolylmethane (DIM) leads to the inhibition of prostate cancer cell growth and migration. J. Cell. Biochem. 2009, 107, 516-527. [CrossRef] [PubMed] 
138. Ahmad, A.; Kong, D.; Wang, Z.; Sarkar, S.H.; Banerjee, S.; Sarkar, F.H. Down-regulation of uPA and uPAR by $3,3^{\prime}$-diindolylmethane contributes to the inhibition of cell growth and migration of breast cancer cells. J. Cell. Biochem. 2009, 108, 916-925. [CrossRef] [PubMed]

139. Kong, D.; Li, Y.; Wang, Z.; Banerjee, S.; Sarkar, F.H. Inhibition of angiogenesis and invasion by $3,3^{\prime}$-diindolylmethane is mediated by the nuclear factor-kappaB downstream target genes MMP-9 and uPA that regulated bioavailability of vascular endothelial growth factor in prostate cancer. Cancer Res. 2007, 67, 3310-3319. [CrossRef] [PubMed]

140. Kong, D.; Sethi, S.; Li, Y.; Chen, W.; Sakr, W.A.; Heath, E.; Sarkar, F.H. Androgen receptor splice variants contribute to prostate cancer aggressiveness through induction of EMT and expression of stem cell marker genes. Prostate 2015, 75, 161-174. [CrossRef] [PubMed]

141. Ahmad, A.; Biersack, B.; Li, Y.; Kong, D.; Bao, B.; Schobert, R.; Padhye, S.B.; Sarkar, F.H. Targeted regulation of PI3K/Akt/mTOR/NF-kappaB signaling by indole compounds and their derivatives: Mechanistic details and biological implications for cancer therapy. Anticancer Agents Med. Chem. 2013, 13, 1002-1013. [CrossRef] [PubMed]

142. Lamouille, S.; Derynck, R. Emergence of the phosphoinositide 3-kinase-Akt-mammalian target of rapamycin axis in transforming growth factor-beta-induced epithelial-mesenchymal transition. Cells Tissues Organs 2011, 193, 8-22. [CrossRef] [PubMed]

143. Sethi, S.; Li, Y.; Sarkar, F.H. Regulating miRNA by natural agents as a new strategy for cancer treatment. Curr. Drug Targets 2013, 14, 1167-1174. [CrossRef] [PubMed]

144. Melkamu, T.; Zhang, X.; Tan, J.; Zeng, Y.; Kassie, F. Alteration of microRNA expression in vinyl carbamate-induced mouse lung tumors and modulation by the chemopreventive agent indole-3-carbinol. Carcinogenesis 2010, 31, 252-258. [CrossRef] [PubMed]

145. Li, Y.; VandenBoom, T.G., 2nd; Kong, D.; Wang, Z.; Ali, S.; Philip, P.A.; Sarkar, F.H. Up-regulation of miR-200 and let-7 by natural agents leads to the reversal of epithelial-to-mesenchymal transition in gemcitabine-resistant pancreatic cancer cells. Cancer Res. 2009, 69, 6704-6712. [CrossRef] [PubMed]

146. Kong, D.; Heath, E.; Chen, W.; Cher, M.L.; Powell, I.; Heilbrun, L.; Li, Y.; Ali, S.; Sethi, S.; Hassan, O.; et al. Loss of let-7 up-regulates EZH2 in prostate cancer consistent with the acquisition of cancer stem cell signatures that are attenuated by BR-DIM. PLoS ONE 2012, 7, e33729. [CrossRef] [PubMed]

147. Watson, G.W.; Beaver, L.M.; Williams, D.E.; Dashwood, R.H.; Ho, E. Phytochemicals from cruciferous vegetables, epigenetics, and prostate cancer prevention. AAPS J. 2013, 15, 951-961. [CrossRef] [PubMed]

148. Li, Y.; Kong, D.; Ahmad, A.; Bao, B.; Sarkar, F.H. Targeting bone remodeling by isoflavone and 3,3'-diindolylmethane in the context of prostate cancer bone metastasis. PLoS ONE 2012, 7, e33011. [CrossRef] [PubMed]

149. Wu, T.; Chen, C.; Li, F.; Chen, Z.; Xu, Y.; Xiao, B.; Tao, Z. 3,3'-Diindolylmethane inhibits the invasion and metastasis of nasopharyngeal carcinoma cells and by regulation of epithelial mesenchymal transition. Exp. Ther. Med. 2014, 7, 1635-1638. [PubMed]

150. Xu, L.; Jiang, Y.; Zheng, J.; Xie, G.; Li, J.; Shi, L.; Fan, S. Aberrant expression of $\beta$-catenin and E-cadherin is correlated with poor prognosis of nasopharyngeal cancer. Hum. Pathol. 2013, 44, 1357-1364. [CrossRef] [PubMed]

151. Yellayi, S.; Naaz, A.; Szewczykowski, M.A.; Sato, T.; Woods, J.A.; Chang, J.; Segre, M.; Allred, C.D.; Helferich, W.G.; Cooke, P.S. The phytoestrogen genistein induces thymic and immune changes: A human health concern? Proc. Natl. Acad. Sci. USA 2002, 99, 7616-7621. [CrossRef] [PubMed]

152. Klein, C.B.; King, A.A. Genistein genotoxicity: Critical considerations of in vitro exposure dose. Toxicol. Appl. Pharmacol. 2007, 224, 1-11. [CrossRef] [PubMed]

153. You, L. Phytoestrogen genistein and its pharmacological interactions with synthetic endocrine-active compounds. Curr. Pharm. Des. 2004, 10, 2749-2757. [CrossRef] [PubMed]

154. Patisaul, H.B.; Jefferson, W. The pros and cons of phytoestrogens. Front. Neuroendocrinol. 2010, 31, 400-419. [CrossRef] [PubMed]

(c) 2016 by the authors; licensee MDPI, Basel, Switzerland. This article is an open access article distributed under the terms and conditions of the Creative Commons Attribution (CC-BY) license (http:/ / creativecommons.org/licenses/by/4.0/). 